\title{
AUTHORIZED OR UNAUTHORIZED: A DILEMMA FOR THE HISTORIAN
}

\author{
David W.J. Gill \\ I. The Unauthorized Version
}

An important work, The Unauthorized Version: Truth and Fiction in the Bible by Robin Lane Fox, ${ }^{1}$ University Reader in Ancient History at Oxford University and Fellow of New College, sets out to examine critically the Biblical texts and asks the question, as the subtitle implies, is the Bible history or fiction? In many ways it is a companion volume to the author's earlier Pagans and Christians ${ }^{2}$ and readers will recognise sections drawn from it, such as the discussion of Sergius Paulus and his links with Pisidian Antioch. ${ }^{3}$ Moreover it is Lane Fox's knowledge of the world of late antiquity which comes to the fore. The title may be puzzling to some and it is explained in the Preface (p. 7) as follows:

It is unauthorized because it addresses questions which the Bible itself obscures: its authors, historical growth and historical truth. It is not an unauthorized version because other people have authorized their own version and wish to suppress the truth in mine.

\section{History and the Unauthorized Version}

The book consists of four parts in twenty-two chapters and is completed by an extensive bibliography which reflects the breadth of Lane Fox's research. Historians will find Part III (Chapters 11-19) the most important section. There is a useful chapter on 'Ideas of History' (Chapter 11) which emphasises the importance of a chronological framework, an approach somewhat characteristic of historians in Oxford.4 This

1Published by Viking in London, 1991.

${ }^{2}$ R. Lane Fox, Pagans and Christians (London, Viking 1986).

${ }^{3}$ p. 307; Pagans and Christians, 293-94.

4An example of this Oxford approach is provided by Hugh Bowden's skilful discussion of chronology in Thucydides and its relationship with the material culture: 'The chronology of Greek painted pottery: some observations', Hephaistos 10 (1991) 49-59. 
methodology is in contrast with, say, a Cambridge method which looks more at themes in history. 5 Indeed Lane Fox reminds us of two important questions to ask of a text:

1 . Is the text purporting to be history? 2. What was the source for the writer of the text?

Lane Fox asks, what is in some ways, a restricted set of questions about the texts, for example about the accuracy of the chronological scheme. Yet it is as well to remember that some ancient historians have a broader view of history. Fergus Millar, Professor of Ancient History in Oxford University, could take Apuleius' fictional Golden Ass and use it to inform about second century AD Greece and in particular Corinth.6 This is indeed how New Testament background studies could develop. Some of the recent work on the Corinthian correspondence would suggest that these were letters addressed to members of the social élite in the Roman colony. Biblical scholars and/or historians could argue that these were letters addressed to real people in real situations. ${ }^{7}$ In fact the New Testament can inform the historian about first century AD Corinth in a way that no other surviving classical text can. If Lane Fox's narrow view of history is taken in treating the gospels as 'history' one can understand why he does not accept that prophecies can appear in an historical document. Thus, for Lane Fox, Jesus' predictions about the destruction of Jerusalem cannot be part of the original text ( $p$. 204). Yet what are his grounds for adapting the text? Does he provide the reader and other scholars with a new text? What does he excise? What are his principles?

The point about texts serving to expand the historical record is illustrated by the Exodus, which Lane Fox sees as little more than a myth to be placed on the same level as the Trojan War (p. 176). Even for a 'myth' like the Trojan War some historians, such as Sir Moses Finley, have accepted a

${ }^{5} \mathrm{~A}$ recent example of this approach is $\mathrm{P}$. Garnsey, Famine and Food Supply in the Graeco-Roman World: Responses to Risk and Crisis (Cambridge, CUP 1988).

6F. Millar, 'The World of the Golden Ass', JRS 71 (1981) 63-75.

${ }^{7}$ Some recent examples could be B.W. Winter, The Importance of the Captatio Benevolentiae in the Speeches of Tertullus and Paul in Acts 24:1-21' JTS n.s. 42 (1991) 505-31; D.W.J. Gill, 'The importance of Roman portraiture for head coverings in 1 Corinthians 11:2-16', Tyn $B$ 41 (1990) 245-60. 
'kernel' of historical truth and stated that 'the Trojan War could have occurred'. 8 If we take the Finley position then the Exodus need not be a 'myth' but indeed could have been an historical event. Yet the issue of the Exodus shows how Lane Fox's position can differ from those familiar with the Near Eastern and Egyptian material. An example of this is the Merneptah stela from Thebes in Egypt which lists Israel as a defeated people rather than as a vanquished land (like the others on the list). This has been taken by some, such as T.C. Mitchell, former Keeper of Western Asiatic Antiquities at the British Museum, to show that the stela reflects a time when the Israelites were unsettled. He dates the stela to $c .1208 \mathrm{BC}^{9}$ and takes it to be prior to the entry into the Promised Land.10 Lane Fox (pp. 225-6) dates the stela to 1220 and suggests that 'before c. $1225 \mathrm{BC}$, . . perhaps as much as two centuries before, we need to look for evidence of burning and desolation of sites in the Promised Land'.

Lane Fox asks legitimate and important questions about treating the gospels as history if they were written some 30-50 years after Jesus' death (p. 202). Yet were they written as history (in the modern sense of the word) or as 'gospel'? If the latter, are the documents a portrait, a biography, or romance? If a chronological approach to the texts is taken, there may appear to be chronological problems for the historian. If a more thematic approach is taken, the gospels can be used to build up a picture of the life and teaching of Jesus. Lane Fox's reluctance to accept the historical basis of the gospels (p. 203) contrasts with the view of another ancient historian, Sherwin White, who commented nearly thirty years ago,

So, it is astonishing that while Graeco-Roman historians have been growing in confidence, the twentieth-century study of the Gospel narratives, starting from non less promising material, has taken so

${ }^{8}$ M.I. Finley, Early Greece: The Bronze and Archaic Ages (London, Chatto and Windus 1977) 63.

${ }^{9}$ The Bible in the British Museum: Interpreting the Evidence (London, British Museum Publications 1988) 41, Document 12.

${ }^{10}$ For the entry see pertinent comments by K.A. Kitchen, 'Israel seen from Egypt: understanding the Biblical text from visuals and methodology', TynB 42 (1991) 124. 
gloomy a turn. . .that the historical Christ is unknowable and the history of his mission cannot be written.'11

Lane Fox presents the book of Acts as 'Christianity through others' misunderstandings', which reflects his view that hearsay was a main source for the writer, and notes that 'Thucydides, king of Greek historians, would have winced' ( $p$. 211). Yet there are some scholars who would accept Acts as history rather than as a series of 'misunderstandings'.12 Adopting such a literary style for presenting arguments is a dangerous path to follow. Just because biblical archaeologists have made some 'howlers' - such as Woolley finding traces of the flood at Ur (p. 218) - that with hindsight look ridiculous does not mean that biblical archaeology (or the Bible) is wrong. The same straw-man arguments could be used against the classical historian Herodotus. Take for example the discovery in the later nineteenth century at Naucratis in the Nile Delta of the historian's signature on sherds of Greek pottery. These are oft quoted as evidence of the historian's visit to Egypt, yet they are cut on sherds which either predate his birth or postdate his death. ${ }^{13}$ Indeed there are some who still believe that they can identify the 'walk-on characters' of Herodotus in the archaeological record. Because of these erroneous views do we dismiss classical archaeology or indeed the classical texts? The answer must be 'no'. If Lane Fox has overlooked errors in his own discipline then he needs to be more tolerant of the past scholarship in biblical studies.

Lane Fox's comments on biblical archaeology are apt. I would agree that it is misplaced to think that archaeology can be used to confirm written records. 14 He notes the problems with the archaeology of the entry into Canaan (p. 225), yet even in Athens, destroyed by the Persians in $480 \mathrm{BC}$ (and recorded by an historian, Herodotus) there is disagreement

${ }^{11}$ A.N. Sherwin White, Roman Society and Roman Law in the New Testament (Oxford, Clarendon Press 1963)

${ }^{12}$ See C. Hemer, The Books of Acts in the Setting of Hellenistic History (Tübingen, J.C.B. Mohr 1989).

${ }^{13}$ D.W.J. Gill, 'Two Herodotean dedications from Naucratis', JHS 106 (1986) 184-7.

${ }^{14}$ Compare, for example, the lack of contact between the extant material culture of classical Greece and the classical texts. D.W.J. Gill, 'Expressions of wealth: Greek art and society', Antiquity (1988) 735-43. 
among archaeologists about what constitutes 'Persian destruction'.15 It is thus a little rash of Lane Fox to affirm that the Entry into Canaan 'is not history and it never was' (p. 229). Indeed, it is notoriously difficult to argue for changed settlement patterns as detected from the data collected on field-surveys. ${ }^{16}$ Yet archaeology can be used to provide evidence which can be formed into a picture of the material and cultural background for the texts. For example inscriptions may tell us about 'god-fearers' (p. 283) or an inscription from Delphi might help to date Paul's visit to Corinth (p. 304).

Lane Fox does acknowledge that the debate, and indeed the thrust of the book, must centre on the person of Jesus:

Only at the heart of Christianity does faith need historical truth: either Jesus rose from the dead or he did not. If he did not, Christianity is untrue. On the available evidence, historians cannot decide the matter; in my view, there is a primary source, the beloved disciple' (p. 360).

If John is such a reliable primary source, what is Lane Fox's response to the Resurrection? By what criteria does he reject the other sources? Herein lies a conundrum for the book. Objectivity is not the prerogative for the historian or the biblical scholar. It is on this point of Jesus which evangelicals (and others) would wish to focus their arguments. It is a point which Lane Fox is unwilling to dismiss outright. Do we accept our witnesses and sources or do we reject them? This brings us to the heart of the book. What are the presuppositions which any ancient historian or biblical scholar, and in this case specifically Lane Fox, brings to their work?

\footnotetext{
15See most recently E.D. Francis and M. Vickers, "The agora revisited: Athenian chronology c. 500-450 BC', Annual of the British School at Athens 83 (1988) 143-67.

16For a helpful discussion on 'the complexity of the relationship between archaeological data and historical process' see J.-P. Vallat, 'Survey archaeology and rural history-a difficult but productive relationship', in G. Barker and J. Lloyd (edd.), Roman Landscapes: archaeological survey in the Mediterranean region, Archaeological monographs of the British School at Rome 2 (London, British School at Rome 1991) 10-17.
} 


\section{A new approach to biblical studies?}

Lane Fox might have made a better case if he had argued in a more straightforward way. His style occasionally veers to ridicule. Is he methodologically correct to undermine a story of the first century $\mathrm{AD}$ (i.e. the Nativity) by looking at what people thought of the incident in subsequent centuries? Of course it is helpful to realise how different peoples and cultures have placed different spectacles over our eyes, yet it must obscure the argument at best (and deliberately mislead the reader at worst) by bringing in much later evidence such as the names of the 'kings' from a sixth century church in Egypt or Marco Polo's visit to Saveh where the bodies were viewed ( $p$. 37). Lane Fox occasionally wishes his thoughts and views back onto figures (both historical and fictional) from the past. He asserts that 'in the age of Solomon nobody is likely to have thought out such a theology' (viz. God's election, promise and covenant) (p. 60).17 Solomon, it is claimed, 'would never have credited' the writings attributed to him. Lane Fox presupposes,

Here were his descendants venerating texts which he was supposed to have written and wondering whether or not they polluted people's hands: he had never composed a word of them. One of them said that he had 'uttered three thousand proverbs and his songs were a thousand and five': it was amazing to be thought so clever. There were even people who thought that he had written the Song of Songs: it would have looked to him like a collection of straightforward love poetry (his Egyptian wife had known plenty of bits like it). Why ever had people fallen for this book of the law in which Moses seemed to speak: why had they dreamed up a covenant with God or a future life? $\mathrm{He}$ and his friends had managed very well without any of them (p. 114).

Lane Fox presupposes that prophecy has not, and does not, exist. Thus if a text belongs to this genre then Lane Fox assumes ipso facto it to have been written with hindsight. That is to say that the prophecies were written as history but made to look like prophecy. Thus the writer of Revelation could have known that there was a famine, that there had been earthquakes etc., and therefore he wrote them into the text as if they were predictions.

${ }^{17}$ See K.A. Kitchen, 'The Fall and Rise of Covenant, Law and Treaty', TynB 40 (1989) 118-135. 


\section{A challenge to 'authorized' Christianity}

Part I (Chapters 1-2) is an attack on orthodox Christianity, or as Lane Fox labels it, 'fundamentalism'. It considers the biblical texts against their historical background. For example, Lane Fox starts with a look at the Creation story and concludes that the biblical text, 'made up from two contradictory sources', does 'not correspond to the facts, for we now know more of the age of the world, the fact of its evolution and the process which stretched beyond six days of work or a garden of greenery near the Euphrates River' (pp. 15-27). His second example is drawn from the story of the Nativity where he attempts to detect problems with the non-historical sources; for example, the dates of Quirinius, the date of Herod's death and the date of the census. Indeed for Lane Fox the star, or 'comet', 'is a construction from well-known messianic prophecies' (p. 35).18 Such questions should be faced and addressed, especially in an area where Christians can and do disagree.

Chapter 2 ('The Unerring Word') builds on Chapter 1's discovery that 'the stories of Creation and the Nativity. . .[do] not correspond to the facts' (p. 39). Lane Fox turns to the question how certain Christians treat scripture today. He states:

The belief that as God's word, scripture never errs has been prominent in evangelical Christianity since the nineteenth century, with important consequences for the uses of scripture in Christian missions throughout the world (p. 39).

Lane Fox draws attention to the fact that if the Bible and history do not correspond (for example, in the discussion in Chapter 1) and if the Bible is God's word, then it 'entails that God tells lies; the Bible. . .is not always true' (p. 40). From here on, Lane Fox adopts the term 'fundamentalist' to describe this broad group of evangelicals, that is to say those who place a high value on scripture. He creates a straw-man argument. If 'fundamentalists' are champions of 'unerring' scripture, and scripture can be found to contain 'error' then evangelicals should not be taken seriously. It is a simplistic view for Lane Fox to suggest that evangelicals sidestep the issue of 'error' by

${ }^{18}$ See now pp. 31-56 on 'The Star of Bethlehem, a comet in 5 BC and the date of Christ's birth', by C.J. Humphreys. 
arguing that 'when properly understood, the Bible is never in error' (p. 40). Evangelical biblical scholars would wish to apply academic rigour to their studies, much as Lane Fox is presenting himself as a rigorous scholar to his readers. Yet within these groups there will not be agreement on what scripture means. As Lane Fox points out, there will be some who will accept the end of Mark's gospel as authoritative and expect to live after being bitten by snakes (p. 144). However some will not wish to place too much weight on what appears on literary or textual grounds to be an added text; that is why some evangelicals accept scripture as being authoritative as it was originally given. ${ }^{19}$ It is typical of Lane Fox's argument to suggest that

Unerring scripture has foundered on the truth of evolution and on scores of subsequent discoveries, to the point where fundamentalism ought to have joined the fossils as an outmoded relic from the past. Most remarkably, it has survived and re-emerged. The challenge of evolution has become so familiar that it has simply been sidestepped or ignored. In the face of it, fundamentalism has held to its principles and, far from being swept away, has profited from a tide which was set up by science's own success (p. 42).

Indeed Lane Fox concludes with the assertion that 'Scripture is not God's word in any strong sense, nor is it unerring, with the possible exception of a few trivial facts' (p. 44). Thus by page 45 (in fact in 32 pages) Lane Fox has 'removed' 'fundamentalism' (or evangelicalism) from the debate that is to follow. Later on in the book, Lane Fox goes on to argue (or assert) that the 'modern' emphasis on scripture is misplaced; for him 'The first Christians were people of faith, not textual fundamentalists' (p. 120). It is for this reason that he casts doubts on the 'fundamentalist' text of 2 Timothy 3:16:

The translation is arguable, as is the text's authority. It is a pleasant measure of the complexities in the Bible's truth: the text which has been misused to support a literal view of the entire Bible's inspiration is itself the work of an author who had lied about his identity (p. 136).

Evangelicals appear to be a thorn in the side, and this becomes apparent in throw-away remarks, such as those

${ }^{19}$ I do not use the word 'written'. Lane Fox's attack on evangelicals and their view of written scripture seems to me misaimed. 
about Old Testament prophets who are seen by Lane Fox as little more than 'a small intolerant group' (p. 62)-the inference is there for a twentieth century parallel. Lane Fox's personal position is made clear when he sees the northern kingdom as being no worse than any other society and he does not understand why the prophets saw it as 'an awful den of sin' (p. 61). Indeed for Lane Fox 'free love and templeprostitution. . .still sounds harmless, perhaps rather charming, for the people on the spot' (p. 62).

In Part II (Chapters 3-10), Lane Fox turns to the biblical texts in detail and although there is likely to be some disagreement, it is more factual. He draws attention to, inter alia, how the canon of scripture was formed, the identification of authors (especially for what he perceives as anonymous works), questions of style (including computer analysis [p. 134]), the importance of oral teaching, revision and editing of the texts, the change from scrolls to books, and the creation of a standard text.

\section{Conclusion}

For many this work will prove to be disappointing. It is a synthesis of what has been written in the area of textual formation and historicity of the Bible; its function is perhaps to make the fruits of this research known to a wider public. Certainly the sections on what constitutes history and the textual methodology (especially Chapters 11 ['Ideas of History'] and 12 ['The First Historians']) are helpful statements which anyone approaching the Bible from a historical perspective would do well to read. It must be a matter of concern that Lane Fox, by his own admission (p. 8), knows no Hebrew and therefore depends on others to come to grips with the nuances of semitic idioms. Thus when there is a divergence of opinion between Lane Fox, a classical historian, and biblical scholars who have a better grasp of the cultural setting, the reader should consider which person is in the best position to assess the available evidence.

Finally, there is a problem about the audience for this book. Biblical scholars will, one hopes, already be aware of many of the arguments used here. Indeed, with their knowledge of Hebrew and other Near Eastern texts they will probably have a better grasp of the material. Ancient 
historians, coming with a classical background, may find Lane Fox's work a useful introduction, but may wish to by-pass it to get to grips with the original debate by going straight to the works of biblical scholars. This leaves a question about Lane Fox's referencing style. There are no notes within the body of the book; at the end there is a running bibliography, ordered page by page. The titles of articles in journals are not cited which would have been helpful. In a way this referencing style, which frees the block of text from footnotes may reflect the fact that this book is aimed at the 'informed public'. All things being said, this is an important book which should prompt biblical scholars to tighten arguments and adopt a more rigorous approach to their texts. It should not be ignored. Biblical scholarship perhaps should place the historicity of the texts higher on the agenda.

This leaves us with a dilemma. Does the historian follow Lane Fox by only accepting texts which have clear and unambiguous authorship. Thus scholars should be able to accept the beloved disciple's authorship of John's gospel. Yet should such questions of authorship be allowed to dominate the historian's research? Or as Finley suggests should he or she be seeking to find 'the reason or the motive for its having been written'.20 If we are to follow Finley, we should be asking what message were the biblical texts trying to communicate? Were they trying to 'memorialize' something or someone? Lane Fox is perhaps himself confused by his own presuppositions. He is, by his own admission, a self-confessed atheist (p. 7) who records that he was once said to have remarked that he 'believed in the Bible and not in God' (p. 8); this book has been written to expand on what, he assumes, is his credal confession.

20Sir Moses Finley, Ancient History: Evidence and Models (London, Chatto \& Windus 1985) 32. 